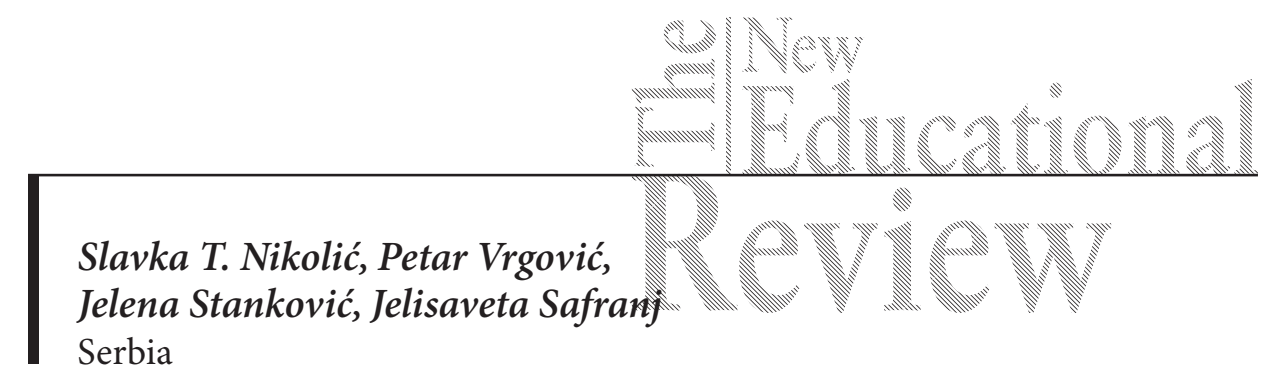

\title{
Students' Emotional State and Educational Efficiency: Temptations of Modern Education
}

\begin{abstract}
While searching for the ways of enhancing students' educational efficiency, the authors set the framework for the issue from two perspectives - educational and emotional, stressing the existence of a strong interdependence between emotional and cognitive ones. The focus of study is students' perception of educational processes, the emotional states they demonstrate and their interdependence. For the purpose of this research a battery of questionnaires was constructed and the results have shown that students' emotional states greatly influence their perception of educational efficiency. Based on these results, the recommendation on modifying the management of educational processes is that students' emotional states should not be excluded from the equation of a successful education. The factors that shape the emotional context of learning should be taken into account.
\end{abstract}

Keywords: education, educational efficiency, perception, emotional status

\section{Introduction}

Speaking of university in the modern, constantly mutating world, Federico Major says: "If it is true that the acceleration of history disturbs our benchmarks, challenging heavily our ability of adjustment, at the same time filling us with hope and anxiety, we are still living in the era that offers a wide range of possibilities, provided that we escape the entrenchment in the institutional, 
more or less enclosed space. Being the critical conscience of society, the task of University is to constantly explore new fields of abilities, if it intends to be true to its vocation, i.e. to forge the future..." (Major, F., 1994: 31). To create and maintain a knowledge-generating ability is a developmental necessity. Education is an increasingly important developmental factor and "open access to good and functional education is the basic assumption to achieve what Rawls (1998: 389) defined as the space of freedom and the income, prosperity and self-esteem opportunities" (according to Z. Stojiljkovic, 2011: 489). Especially, requirements of "deindustrialization and the shift to a post-industrial society have contributed to an evolution in the organization and operations" (Bettis, 1996: 105), and therefore, it dictates the requirements for establishing an effective education system. The effects of deindustrialization and the gradual shift toward, also called the postindustrial, information, or high-technology society have had a significant impact on political, social, and economic relations" (Bettis, 1996: 106) in many countries, and also in the former Yugoslavia.

Modern education "should encourage creative work, research and discomfort"; it has to create self-confident people ready for "non-conformism, personal choice and responsibility, for truth away from stereotypes and unquestionable authorities" - none of it is possible without caring, confident, educated and competent people (Nikolić, T.S. et al., 2011:20).

What can be an obstacle to the achievement of educational effectiveness, what are the possible ways of removing the obstacles and how to facilitate the achievement of this goal? In searching for ways of increasing educational efficiency, the authors set the framework for the investigation from two perspectives - educational and emotional, with the research focus on students of engineering faculties (future engineers) from the former Yugoslavia.

Yugoslav countries are classified into the group of so-called "belated nations" (verspatete Nation/late coming country), where "science and technology are not timely accepted as the ideology of modernization", as an essential factor of development. The symptom of "blocked society" has become a difficult obstacle to development. The disintegration of Yugoslavia (SFRY) was marked by a series of armed conflicts in the former Yugoslav republics (1990-1999). The fierce ethical conflicts between the nations of the former Yugoslavia had strong economic, political, ethnic and religious roots and are considered "the bloodiest conflict in Europe since the Second World War." Replacing the SFRY, five new countries were created: Slovenia, Croatia, Macedonia, Bosnia and Herzegovina, Montenegro and Serbia. All the time, consciously or unconsciously, they have been suffering the 
(often fatal) effects of prevailing ideology ${ }^{1}$, where ideology influences the perception, perception shapes expectations, and expectations in turn shape behavioral tendencies.

Do parts of the former Yugoslavia behave as "communicating vessels"? Will the former common space, cultural pattern, educational environment, etc., continue to express its strength, if reflected through the same/similar perceptions? Will, and which colors, the lack of desperately needed peace, 'paint', visibly and invisibly, the lives of current generations? To what extent and in what direction do emotions affect the course and results of the education process? And finally, should it be an (important) part of our professional and highly human (educational) interests? These are all the issues by which the 'dramatic background' of this research was driven.

Events experienced by the people of the former Yugoslavia, the changes occurring with or without them, have imposed the need for revising the educational (and not just educational) identity ${ }^{2}$. As Jovan Cvijic (1922) emphasized, "every nation in Europe has achieved or will achieve a remarkable level of material culture provided that it has lived in peace for many years..." In one word, without the presence of (long term) peace and sovereignty, there cannot be (scientific) knowledge, (good) education, and development of technological and organizational capabilities... - there is no development! Therefore, it can also be concluded that learning and students' quality of life in public and private schools are very different and influence education efficiency (Morgan, 1983).

\section{Theoretical framework}

Emotions do not arise in a vacuum, they do not occur by themselves; instead, they are inseparable from the human who feels them, the same way he is inseparable from the life situation where he senses the given feeling. "Emotion is always a response of a human to an event.” (Milivojević, Z.; 1999: 12). Understanding the perception that "feelings provide insight ... How we understand the world, what values we have, what is important to us... - all this is revealed by the way we behave sensitively" (Grelan, H., 2007) that "emotions are connecting what is important to us with the world of people, things and events (Oatley, K., Jenkins,

\footnotetext{
1 Ideology - human beliefs on the ways societies need to be organized and their mutual relationships (according to J.W. Fulbright, 1996, p. 164).

${ }^{2}$ It is also necessary to revise our current political, public, economic and cultural identity.
} 
JM, 1996), new contexts of the educational process and alternative paths are revealed for increasing educational efficiency.

Emotions are an inevitable part of life and therefore of the learning process as well. More than two thousand years ago Plato argued that emotions underlie all learning. Beliefs that students of technical faculties are strictly rational and that emotions lack any significant impact on the learning process and its effectiveness, are the result of an insufficient understanding of emotions or it is a typical stereotype. As indicated by research conducted in the first decade of this century (Nikolić, T.S. et al., 2011a), there are certain differences in the emotional status of students - future engineers and students - future psychologists, but these do not support the aforementioned stereotype. What contributes to the success of students (whether of technical sciences or humanities) is their ability to manage emotions instead of their exemption.

Educational research (Sylva et al., 2004, Thorpe et al., 2004) confirms the importance of early experiences and environments in the child's development and learning. The importance of the "quality of early experiences for the child's short-term cognitive, social and emotional development, as well as its long-term success in school and later in life" is obvious (OECD, 2007: 56). Results of numerous studies increasingly highlight the importance of several environment-related factors for the learning process. Emotions govern (or hinder) psychological processes, such as attention-focusing, problem solving or relationship-supporting abilities..." (OECD 2007: 84). Different studies have also confirmed that negative emotions block the learning process. Fear or stress-induced emotional conditions directly impact on the process of learning and memorizing (Damasio, 1994; LeDoux, 2000).

Stressing the strong interdependence of the emotional and cognitive factors, there is a growing body of evidence "confirming that our emotions are reshaping/ modifying the nervous tissue. In the case of exceptional stress or intense fear, social reasoning and cognitive skills suffer as a result of compromise of neural processes of emotional regulation. Emotions make an unavoidable and powerful part of life and learning" (OECD, 2007: 19). If the individual expresses more pronounced neurotic tendencies, or if the person is emotionally unstable, immature, prone to the sense of guilt in his actions, he exploits his intellectual potentials less effectively. This means that one cannot expect effective cognitive activity in the presence of negative emotional states. In other words, unless the person is rigid, neurotic, aggressive, etc., he is in the position to adequately and consistently use his intellectual capacities to adjust to new and different situations that are always packed with many obstacles. 
If we accept the view that negative emotions block learning procedure, that "memorizing events or information may be enhanced by strong emotional states or by a specific context, increased motivation and attention," we cannot remain indifferent to the possibility of identifying these emotional states and responding to them in an appropriate manner. Research supports the thesis that growing up in "extreme social environments" leads to significant changes in social interactions, and early social experiences are extremely important for the development of brain systems, relevant to the key aspects of human social behavior. This conclusion becomes more important when we know that the birth, childhood and early adolescence of our respondents (future engineers) are related to the period of the beginning and escalation of armed conflicts in the area of the former Yugoslavia, regardless of where they experienced the war: 'in their own backyard' or 'in the nearest neighborhood'.

In line with these considerations, we share a strong belief that today's universities and schools should focus more attention on the creation of a more favorable, supportive environment that facilitates the development and creation of conditions for transforming intellectual and other potentials of participants in the educational process into operational efficiency.

\section{Research Methodology}

This empirical research, aimed to explore the perception of educational efficiency and emotional states of engineering students, was conducted in the countries of the former Yugoslavia: Serbia, Croatia, Bosnia and Herzegovina, Slovenia and Macedonia. The sample of the first and second year students of engineering universities or engineering departments consisted of 2073 individuals (Serbia 690, Bosnia and Herzegovina 472, Slovenia 234, Croatia 442, Macedonia 235), with $62 \%$ being male and $38 \%$ female. It is important to point out that the birth, childhood, and early adolescence of our respondents was related to the period of starting and escalating of the war in the former Yugoslavia. The research methodology meets the specified purposes of research and is based on a combination of qualitative and quantitative methods. Data were collected with the use of a survey, which consisted of three parts. The first part consisted of 5 general questions. The second part consisted of 21 questions measuring different aspects of perception of educational environment (Appendix 1). This part was constructed following conclusions of another author's research (Dee, 2007), which showed that students' evaluations of courses were highly correlated with teaching methods, organization, preparation and teachers' 
interaction with students. The third part consisted of 66 items of a modified Positive and Negative Affect Schedule (PANAS-X) scale (Watson, Clark and Tellegen, 1988), called PANAS-X+. This part of the survey measured students' emotional conditions in the last year, calculating the following emotions: joviality, self-assurance, attentiveness (positive emotions); fear, sadness, guilt, hostility (negative emotions); shyness, fatigue, serenity, surprise (other emotions). Additional 3 items, not presented in the standardized PANAS-X questionnaire, were included to measure the level of being inspired (inspired, guided and creative) and 3 items measured the level of students' demotivation (bored, demotivated and conditioned).

The following hypotheses were formulated:

1. H1: There is a statistically significant difference in the perceptions of the educational process of students by the country of study.

2. H2: There is a statistically significant difference in the emotional status of students by the country of study.

3. H3: There is a correlation between the emotional status of students and their perceptions of the educational process.

\section{Research results and discussion}

To test hypotheses $\mathrm{H} 1$ and H2, ANOVA tests for mean differences were performed for the dimensions of perceptions of educational environment, as well as emotional states. The following table presents means and standard deviations for the dimensions of perceptions of educational environment for every country (Table 1).

Table 1. Means and standard deviations for the dimensions of perceptions of educational environment by country

\begin{tabular}{llllllllllll}
\hline & \multicolumn{2}{c}{ Serbia } & \multicolumn{3}{c}{$\begin{array}{c}\text { Bosnia and } \\
\text { Herzegovina }\end{array}$} & Slovenia & & \multicolumn{2}{c}{ Croatia } & \multicolumn{2}{c}{ Macedonia } \\
& & Mean & SD & Mean & SD & Mean & SD & Mean & SD & Mean & SD \\
\hline Teaching contents & 22.77 & 3.274 & 21.74 & 3.565 & 21.72 & 2.793 & 20.90 & 3.411 & 20.84 & 4.186 \\
\hline Teaching activity & 25.76 & 3.681 & 23.34 & 3.935 & 25.74 & 3.748 & 22.81 & 3.511 & 22.71 & 4.252 \\
\hline Usefulness & 25.59 & 4.271 & 23.46 & 4.467 & 26.00 & 3.335 & 22.48 & 4.317 & 22.75 & 5.248 \\
\hline Teachers' care & 15.29 & 2.604 & 13.99 & 3.082 & 14.40 & 2.254 & 14.28 & 2.776 & 12.71 & 3.718 \\
\hline Inspiring & 11.26 & 1.980 & 11.03 & 2.059 & 9.64 & 2.194 & 10.45 & 2.001 & 10.86 & 2.402 \\
\hline $\begin{array}{l}\text { Overall educational } \\
\text { process }\end{array}$ & 78.11 & 9.542 & 72.12 & 10.816 & 74.85 & 8.880 & 70.54 & 10.021 & 69.75 & 13.099 \\
\hline
\end{tabular}


Significant differences in the means between countries are shown in Table 1 (significant at .05 level). It can be concluded that the dimensions of perceptions of educational environment vary significantly between the studied countries, which may lead to the conclusion that some factors that exist in national surroundings may contribute to specific educational environments. This result confirms the $\mathrm{H} 1$ hypothesis, which states that there are significant differences between the studied countries regarding the dimensions of perceptions of educational environment.

Table 2 presents means and standard deviations of emotional states for every country.

Table 2. Means and standard deviations of emotional states by country

\begin{tabular}{|c|c|c|c|c|c|c|c|c|c|c|}
\hline & \multicolumn{2}{|c|}{ Serbia } & \multicolumn{2}{|c|}{$\begin{array}{c}\text { Bosnia and } \\
\text { Herzegovina }\end{array}$} & \multicolumn{2}{|c|}{ Slovenia } & \multicolumn{2}{|c|}{ Croatia } & \multicolumn{2}{|c|}{ Macedonia } \\
\hline & Mean & SD & Mean & SD & Mean & SD & Mean & SD & Mean & SD \\
\hline Fear & 12.47 & 4.355 & 13.52 & 4.472 & 13.26 & 4.099 & 12.97 & 4.666 & 13.23 & 4.772 \\
\hline Hostility & 11.69 & 2.947 & 11.60 & 3.000 & 12.22 & 3.437 & 12.00 & 3.733 & 12.18 & 3.975 \\
\hline Guilt & 9.94 & 3.582 & 11.24 & 3.789 & 10.90 & 4.872 & 11.29 & 4.102 & 12.04 & 4.084 \\
\hline Sadness & 9.49 & 3.689 & 10.25 & 3.973 & 9.83 & 4.149 & 9.80 & 4.087 & 9.25 & 3.763 \\
\hline Joviality & 27.24 & 4.948 & 25.28 & 5.114 & 25.67 & 4.683 & 23.74 & 4.779 & 25.54 & 5.434 \\
\hline Self-Assurance & 20.58 & 3.750 & 19.22 & 3.976 & 19.03 & 3.574 & 18.67 & 3.972 & 19.16 & 3.626 \\
\hline Attentiveness & 14.31 & 2.505 & 13.25 & 2.667 & 13.74 & 2.431 & 12.78 & 2.527 & 13.91 & 2.643 \\
\hline Shyness & 7.28 & 2.687 & 7.94 & 2.972 & 6.71 & 2.264 & 7.12 & 2.710 & 7.63 & 2.950 \\
\hline Fatigue & 10.81 & 3.412 & 11.66 & 3.363 & 11.22 & 3.164 & 11.54 & 3.229 & 10.33 & 3.474 \\
\hline Serenity & 10.32 & 2.316 & 10.01 & 2.405 & 8.65 & 2.022 & 9.46 & 2.283 & 10.45 & 2.592 \\
\hline Surprise & 9.58 & 1.622 & 9.21 & 1.637 & 9.35 & 1.177 & 9.15 & 1.611 & 8.45 & 1.963 \\
\hline Being inspired & 10.63 & 2.241 & 9.63 & 2.222 & 9.60 & 1.961 & 9.10 & 2.243 & 9.94 & 2.566 \\
\hline Demotivated & 4.54 & 1.844 & 5.28 & 2.398 & 5.03 & 1.919 & 5.52 & 2.158 & 5.94 & 2.356 \\
\hline
\end{tabular}

Significant differences in the means between the countries are shown in Table 2 (significant at .05 level, using ANOVA procedure). It can be concluded that the students in these countries vary significantly in their emotional states profiles, which may lead to the conclusion that there are some specificities in the studied countries that generate specific emotional states among the engineering students. This result confirms the $\mathrm{H} 2$ hypothesis, which states that there are significant differences between the studied countries regarding students' emotional states. 
Correlations between general dimension scales and dimensions of the perception of educational environment were calculated using Person's $r$ coefficient, as shown in Table 3. All the correlations were significant at $p=.01$ level. Generally positive emotions are in a moderate positive correlation with all the dimensions of the perceptions of the educational environment, as well as with the perceptions of the overall educational process. Generally negative emotions are only marginally correlated with the dimensions of the perceptions of the educational environment. The findings confirm the $\mathrm{H} 3$ hypothesis, which states that there is a correlation between students' emotional states and their perceptions of the educational environment.

Table 3. Correlation between emotions and perceptions of educational environment

\begin{tabular}{lcc}
\hline & $\begin{array}{c}\text { Generally positive } \\
\text { emotions }\end{array}$ & $\begin{array}{c}\text { Generally negative } \\
\text { emotions }\end{array}$ \\
\hline Teaching contents & $.455^{* *}$ & $-.176^{* *}$ \\
\hline Teaching activity & $.408^{* *}$ & $-.209^{* *}$ \\
\hline Usefulness & $.457^{* *}$ & $-.152^{* *}$ \\
\hline Teachers' care & $.313^{* *}$ & $-.173^{* *}$ \\
\hline Inspiring & $.463^{* *}$ & $-.131^{* *}$ \\
\hline Overall educational process & $.513^{* *}$ & $-.220^{* *}$ \\
\hline
\end{tabular}

Furthermore, since the research aimed to explore the connection between students' emotional states and their perceptions of the educational environment, linear regression analysis was performed between emotional states scales of PANAS-X+ and overall educational process evaluations of each student. The obtained model summary states that $\mathrm{R}$ coefficient is .744, with $\mathrm{R}$ square coefficient being .554, at .00 significance level, which leads to the conclusion that students' perceptions of the educational process is significantly influenced by their emotional states.

Table 4 shows noteworthy factors of the perceptions of the educational process among the PANAS-X+ emotion scales. It can be seen that the scales that are part of the "Basic Negative Emotion Scales" list have negative coefficients, meaning that they lower the grade of the educational process perception. The scales of the "Basic Positive Emotion Scales" list and "Other Affective States" list have positive coefficients, which means that they increase the grade of educational process perception. 
Table 4. Coefficients of linear regression model variables

\begin{tabular}{lcc}
\hline & $\begin{array}{c}\text { Standardized } \\
\text { Coefficients Beta }\end{array}$ & Sig. \\
\hline Fear & -.123 & .000 \\
\hline Hostility $^{*}$ & -.058 & .004 \\
\hline Guilt $^{*}$ & -.093 & .000 \\
\hline Joviality $^{\star}$ & .084 & .000 \\
\hline Attentiveness $^{\star}$ & .130 & .000 \\
\hline Shyness $^{*}$ & .071 & .000 \\
\hline Surprise $^{*}$ & .510 & .000 \\
\hline Inspired $^{*}$ & .152 & .000 \\
\hline Demotivated $^{*}$ & -.174 & .000
\end{tabular}

* - significant at .01 level

Dependent Variable: Overall educational process

Figure 1 shows a scatterplot of the predicted dependent variable versus the measured dependent variable, where linearity can be observed leading to the conclusion that the model of the perceptions of the educational process influenced by emotional states can be confirmed.

Figure 1. Scatterplot of predicted vs. observed values for overall educational process variable

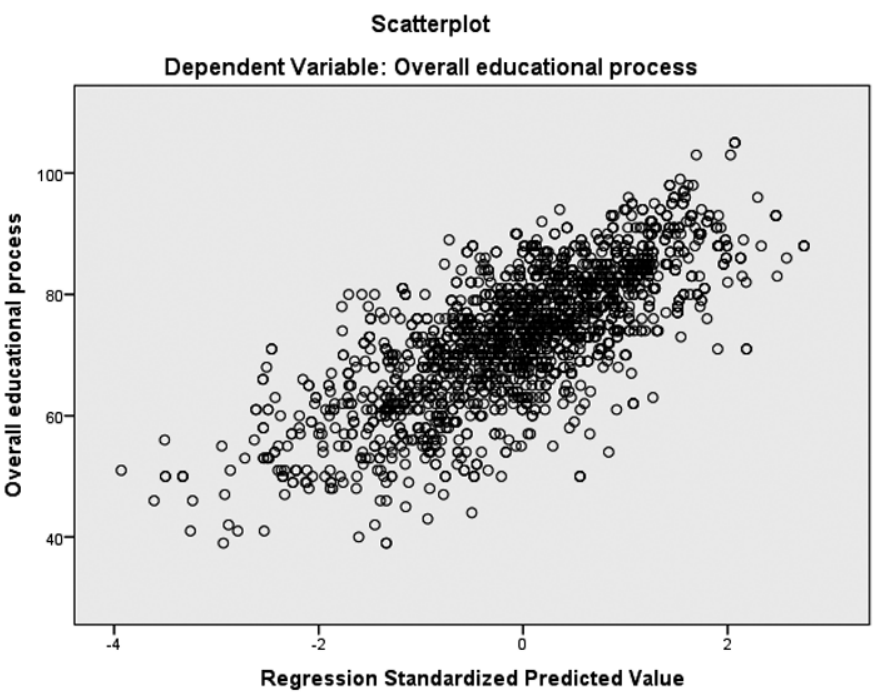




\section{Conclusions}

The presented results are the basis for investigating the differences between the studied countries both regarding the students' emotional conditions as well as their perceptions of the educational process. The main purpose of this study was to determine the dependence of subjective perceptions of the educational effectiveness of the factors existing in students' environment, assuming that such factors will be internalized and manifested in the form of different feelings. Furthermore, as indicated by research results, there are significant differences between the surveyed countries regarding the evaluation of effectiveness of the educational process, while noting significant differences between the students from the surveyed countries regarding their expressed emotional conditions.

This paper sets the framework for investigation from two perspectives - educational and emotional, with the research focused on the students of technical faculties (future engineers) from the former Yugoslavia. Without any intention to deny the necessity of a well-conceived curriculum, the research emphasized the importance and influence of the respondents' emotional status for the success of education. Based on the results, it was found that the students' perceptions of educational efficiency are highly influenced by their emotional conditions, i.e. that the perceptions of educational efficiency can be predicted by the students' emotional conditions. The students with higher levels of generally positive emotions perceive all the aspects of the educational process as ones of a higher quality; they also assess the educational processes in which they participate with a higher overall score.

An efficiency-improving reform of the education system that fails to include the dimension of the development of positive emotions influencing the effectiveness will result in mechanical knowledge-acquiring and instrumentation of the learning process. The authors believe that one of the ways to increase educational efficiency in the streamlined teaching process is certainly the creation of a working environment that decreases negative moods and fear, channels aggression, increases confidence and (above all) increases students' attention.

Teaching activity that encourages and enables creativity, both students' and professors', has a particularly beneficial effect on emotions in the teaching procedure. We are aware of the fact that boredom 'colonizes' the educational space, but teaching activity can be interesting and attractive as well. We are aware of the fact that fear interferes with successful learning instead of supporting it. We know that emotions are side effects of various social relationships in the educational process, both between teachers and students and among students as well. We are aware 
of the fact that different emotions relate competition and rivalry, as opposed to cooperation and mutual support.

Despite numerous uncertainties and possible dilemmas, one thing is certain: the above results indicate a pronounced correlation between emotions, emotional conditions and learning processes and educational effectiveness. They strongly support the thesis regarding the role of emotions: factors shaping the emotional context of the learning procedure should be taken into account. The environmental impact in the learning process is strong; however, the emotional context is still often neglected. Research results have confirmed that beliefs that the students of technical faculties are strictly rational and that emotions have no significant impact on the learning process and its effectiveness are the result of an insufficient understanding of emotions or it is a stereotype. Given that overall human behavior is the result of our thoughts and feelings, i.e. cognitive and emotional activities, it is obvious and almost mandatory to recognize this property for the educational process and educators.

Acknowledgements: This paper results from the "Perception of Educational Environment in the Region of Former Yugoslav Republics" project, carried out with the support of the King Baudouin Foundation and the National Lottery, Brussels, Belgium

\section{References}

Bettis, P.J. (1996). Urban Students Liminality and the Postindustrial Context. Sociology of Education, 105-125.

Cvijic, J. (1922). Balkansko poluostrvo i jugoslovenske zemlje: osnove antropogeografije [The Balkan Peninsula and the South Slavic Countries: foundation of anthropogeography] (Zagreb: štamparski zavod; repr. 1987, Sabrana dela, ii, Belgrade: SANU).

Damasio, A.R. (1994). Descartes' error: Emotion, Reason and the Human Brain, G.P. Putnam, New York.Dee, K.C. 2007 Student perceptions of High Course Workloads are Not Associated with Poor Students Evaluations of Instructor Performance. Journal of Engineering education 96 (1): 69-78

Grelan, H. (2007). Filozofija osećanja, Geopoetika, Beograd.

Inđić, T. (2009). Tehnologija i kulturni identitet, Službeni glasnik, Beograd. Kujic, G. (1991). Linden blossom in the Balkans. Narodna knjiga, Beograd. 
LeDoux, J.E. (2000). Emotion Circuits in the Brain, Annual Review of Neuroscience, 23: $155-184$.

Milivojević, Z. (1999). Emocije - psihoterapija i razumevanje emocija, Prometej, Novi Sad.

Morgan, W.R. (1983). Learning and Student Life Quality of Public and Private School Youth. Education of Sociology, 187-202.

Nikolić, T.S. (2011). Menadžment između mislećeg i osećajnog (Management between Sense and Sensibility), Novi Sad, FTN Publishing.

Nikolić, T.S., I. Ćosić, P. Vrgović, J.Šafranj, and M. Strak. (2011a). Perception of Educational Environment in the Region of Former Yugoslav Republics, PER_EDU; Novi Sad, FTN Publication.

Nikolić, T.S, and M.Pecujlija. (2012). Customer behavior in the culture of fear and short attention, African Journal of Business Management, 6 (9): 3147-3155.

Oatley, K., and J.M. Jenkins. (1996). Understanding emotion; Malden, MA, and Oxford, UK: Blackwell.

OECD. (2007). Understanding the Brain: the Birth of a Learning Science (Centar za obrazovne istraživanja i inovacije: Razumeti mozak: Rođenje nauke o učenju, Ministarstvo prosvete Srbije i Zavod za udžbenike, Beograd)

Shelveson, R., Towne, L. (2002) Scientific Research in Education. National Accademy Press, Washington D.C.

Stojiljkovic, Z. (2011). Srbija u lavirintu tranzicije, Službeni glasnik, Beograd.

Sylva, K., E. Melhuish, P. Sammons, I. Siraj-Blatchford and B. Taggart. 2004. The Effective Provision of Preschool Education (EPPE) Project. Final Report, Department for Education and Skills, London.

Thorpe, K.C. Tayler, R. Bridgstock, S. Grieshaber, P. Skoien, S. Danby and A. Petriwskyj. (2004). Preparing for School. Report of the Queensland School Trials 2003/4, Department of Education and the Arts, Queensland Government, Australia.

Watson, D., Clark, L.A. and A. Tellegen. (1988). Development and validation of brief measures of positive and negative affect: The PANAS Scales. Journal of Personality and Social Psychology, 47: 1063-1070. 